\title{
Križanje, Cerkev in evharistija $v$ treh arturjanskih rokopisih
} Ključne besede: Križanja, Cerkev, evharistija, ikonografija, knjižno slikarstvo,
Estoire del saint Graal

DOI: 10.4312 /ars.11.1.75-89

\section{Branje slike, razbiranje podobe}

Bralec, ki odpre knjigo, v kateri so poleg besedila tudi ilustracije, ob njihovem ogledovanju v svojih mislih ustvarja njihov opis, saj je to edini način, da jih opomeni, to je da jih z območja okrasnega prenese na območje vsebinskega. Miselno ustvarjanje opisa je edina pot, po kateri je mogoče priti do odgovora na vprašanje, »kaj je na sliki upodobljeno", pomeni pa razbiranje pomenov, ki so z oblikami, kompozicijami, barvnimi razmerji itd. slikarsko izraženi, drugače rečeno: pomeni "prevajanje» slikarskega izraza v besedni izraz, pripisovanje pomena besed, stavkov, pa tudi celih besedil (besednega teksta) zelo drugačnim izraznim sredstvom, elementom drugačnega znakovnega sistema, drugačnega "jezika« (namreč: likovnega, nebesednega). ${ }^{1} \mathrm{~V}$ bralčevih mislih tako opomenjanje ne nastaja iz praznine, temveč iz arhiva, zakladnice, baze, shranjene oz. obstoječe v bralcu kot subjektu opomenjanja; to pomeni, da je sleherno opomenjanje slike (likovnega teksta) v resnici vpisovanje pomenov, ki so subjektu znani (od drugod), v sliko, ki jo ima prvič pred sabo. Razbiranje pomenov na sliki tako ni nič drugega kot vpisovanje pomenov v sliko, iz katere na ta način nastaja podoba (pomen likovnega teksta, njegova »zgodba«). Vpisovanje pomenov pa ne pomeni le identifikacije posameznih elementov (motivov), temveč tudi upoštevanje razmerij med njimi, kar je odločilno zlasti v primeru večpomenskih motivov: njihov konkretni pomen na konkretni sliki je določljiv šele $\mathrm{z}$ ozirom na omejitve, ki mu jih postavljajo drugi motivi, vključeni v isto sliko.

Pravkar opisano »branje« slik ni zgodovinsko omejeno, velja tako za sodobnega kot za srednjeveškega bralca/gledalca. Tako ustvarjenega pomena, podobe, zato ni mogoče pripisati nobenemu konkretnemu bralcu/gledalcu (z izjemo sebe samega, pa še to le v določenem trenutku), kar pa ne pomeni, da se je treba odpovedati poskusu razumevanja, kako je srednjeveški bralec razumel (bral) slike v rokopisih v času, ko so ti rokopisi

1 Med tekstualno in zgodbeno ravnjo ločujem v naratološkem smislu, cf. Bal, 1997. 
nastali. Mora pa nam oznaka »srednjeveški bralec« tu pomeniti »idealnega«bralca, torej ne konkretne osebe, marveč subjekt, ki na podlagi določenega likovnega izdelka (slike) razbira (ustvarja) njen pomen (podobo) na podlagi »idealne« ikonografske vednosti, tj. opomenja sliko s črpanjem razlag iz celotne zakladnice pomenov, ki so za določen motiv obstajali v obravnavanem obdobju in so nam znani. Ne moremo namreč odgovoriti na vprašanje, kaj je konkretni, določeni bralec v nekem času vedel; do določene mere pa moremo odgovoriti na malce drugače zastavljeno vprašanje, namreč: kaj je lahko vedel. Podoba, ki nastane na podlagi takšnega branja, je zgodovinsko mogoča, saj ne upošteva pomenov, ki so izpričani šele pozneje $\mathrm{v}$ času. $\mathrm{V}$ iluminiranih rokopisih, $\mathrm{v}$ katerih posamezne miniature pomensko ne stojijo vsaksebi, marveč so razvojne stopnje ene zgodbe, lahko kot dodaten kriterij (poleg zgodovinske izpričanosti posameznih pomenov in omejitev, ki si jih pomensko postavljajo elementi na eni miniaturi) za oženje polja mogočih pomenov uvedemo razmerja med miniaturami - šele z njihovo analizo, tj. z upoštevanjem dialoga med miniaturami, lahko točneje določimo, kateri pomen posameznega motiva je na sliki poudarjen, izpostavljen, izbran med mogočimi; lahko bi rekli, da je izločevalni kriterij tu (krovna) tema, ki povezuje več miniatur.

V tem članku se želim posvetiti miniaturi, na kateri je upodobljeno Križanje, in sicer $\mathrm{v}$ treh rokopisih Zgodbe o svetem gralu (Estoire del saint Graal), ki so nastali v istem času (pribl. 1315-1325), (v večji meri) v isti delavnici in na podlagi istega modela. Gre za rokopisa, ki sta danes hranjena v British Library v Londonu (BL, Add. 10292, BL, Royal 14.E.III), in za rokopis, ki je od leta $2010 \mathrm{v}$ zasebni lasti, prej pa je bil sedemindvajset let v Amsterdamu (njegova nekdanja signatura je Amsterdam BPH 1 (ex-Phillipps 1045/7 in 3630)). ${ }^{3}$ Analiza miniature Križanja, ki je v vseh treh rokopisih podobna, razlikuje se le v nekaj podrobnostih, bo potekala na zgoraj opisani način: najprej bodo preverjeni mogoči pomeni posameznih motivov, tudi glede na njihova medsebojna razmerja; nato bo podoba, kakršna nastaja iz pomena motivov in njihovega součinkovanja, preverjena glede na druge miniature v posameznem rokopisu, da bi tako ugotovili, ali med njimi obstaja tematska zveza, in razbrali eno od pomenskih niti, ki določajo slikovno naracijo $\mathrm{v}$ obravnavanem rokopisu. $\mathrm{Na}$ ta način se bo nazadnje izoblikoval opis miniature, opis pomena slike, ekfraza podobe, ki jo sugerira slikovni tekst. Gre torej za dvojno prevajanje: bralec/gledalec, ki je videl miniaturo, je moral najprej razbrati (»prevesti« v besedilo v svojih mislih) posamezne elemente, gradnike slike, pri čemer jim je pripisal pomene, ki jih je poznal od prej; te je nato dopolnil/modificiral z branjem besedila in šele tako je konkretna upodobitev dobila konkretni pomen v kontekstu konkretnega kodeksa. ${ }^{4}$

2 Nastali so na področju Saint-Omerja, Thérouannea, Tournaija in Ghenta. Za datacijo, provenienco, slogovni opis in osnovna razmerja med rokopisi gl. Stones, 2013b, 364-366; Loomis, 1938, 97-98.

3 Zaradi lažje preglednosti jih bom v razpravi imenoval rkp. A (nekdanji amsterdamski), rkp. B (BL Royal 14.E.III) in rkp. C (BL Add. 10292).

4 O branju, ustvarjanju miselnih podob na podlagi branja in njihovem interpretativnem razvijanju cf. Carruthers, 1998. 


\section{Identifikacija motivov}

Upodobitev Križanja v dveh rokopisih iz skupine, B (f. 7r, Slika 2) in A (f. 6v, Slika 1), stoji na začetku odlomka, ki govori o tem, kako je Jožef iz Arimateje posodo, iz katere je Jezus pil pri zadnji večerji, napolnil s krvjo umrlega Kristusa; v rkp. C (f. 3v, Slika 3) pa ta upodobitev stoji nekoliko prej, in sicer na začetku "prave« zgodbe o svetem gralu, tj. ločuje jo od prologa. ${ }^{5}$ Jožefova pridobitev svetega grala je osrednje dejanje prvega "poglavja« zgodbe, zato umestitev miniature na njegov začetek ni nenavadna, saj je s tem poudarjen bistveni dogodek v sledečem besedilu; edina druga miniatura v tem poglavju v C je upodobitev kaznovanja Kajfe (f. 4r), ki jo je mogoče brati kot kaznovanje odgovornih za Kristusovo smrt, ki je bila prikazana na prvi miniaturi - zgodba prvega poglavja je tako tudi v slikovni naraciji sklenjena. V rkp. A v prvem poglavju ni nobene druge upodobitve, zato se slikovna naracija v njem ne razvije, izpostavljen je le osrednji dogodek, ki je pomemben za nadaljevanje zgodbe. Največ upodobitev pa je v rkp. B, in sicer poleg obeh, kakršni sta v C (kaznovanje Kajfe je na f. 9r), še upodobitev Jožefa pri pridiganju (f. 9v), ki sledi kaznovanju odgovornih za Kristusovo smrt. Gre za prvo dejanje njegove misijonarske dejavnosti, pokristjanjevanja, ki je ena osrednjih tem Estoire del saint Graal, tako pa je upodobitev bolj kot sklenitev prvega poglavja že usmeritev v nadaljevanje zgodbe.

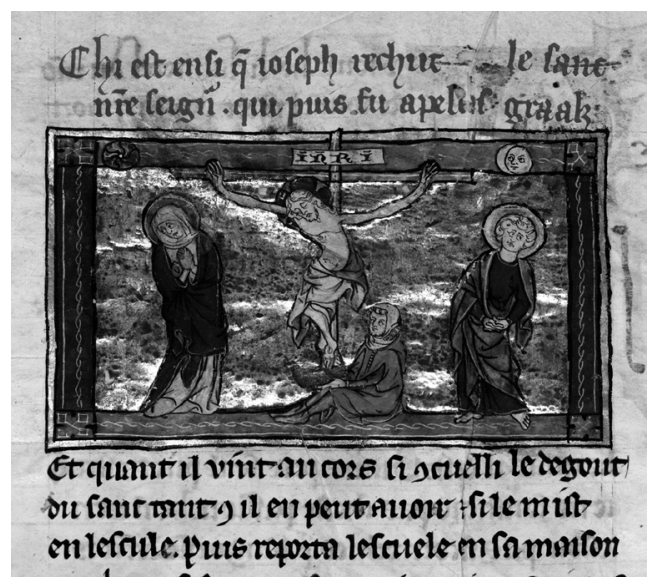

Slika 1: Križanje; pribl. 1315-1325, olim Amsterdam BPH 1 (ex-Phillips 1045/7, 3630), f. 7r.

Vir: http://www.lancelot-project.pitt.edu/LG-web/Arthur-LG-ProjectMSS-pics/ AM1-BPH/AM1-EG-ff1-118v-1600-CP-JCM/AM1-EG-f006v-1600-CP-01-JCM.jpg.

5 V B se »prava« zgodba začne na f. 6v, v A na vrhu f. 6r. Pri slednjem je »novo poglavje« nakazano z inicialo, ki sega čez pet vrstic, pri Royal pa z miniaturo, na kateri je upodobljen pripovedovalec pri prepisovanju knjige. 


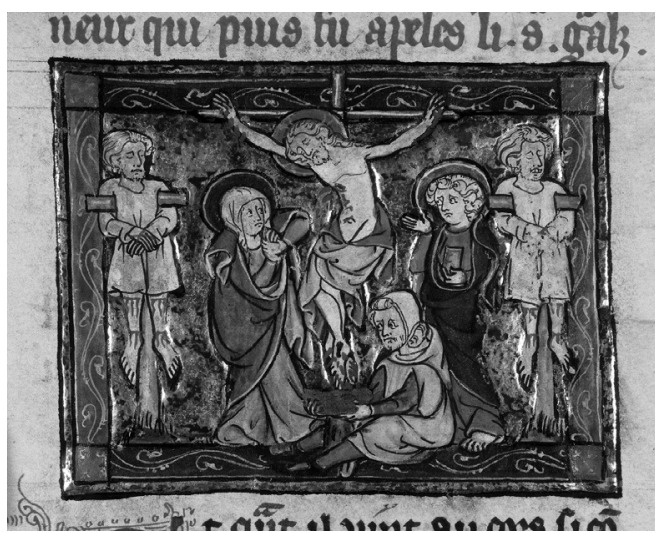

Slika 2: Križanje; pribl. 1315-1325, British Library, Royal 14.E.III, f. 7r. Vir: http://www.bl.uk/catalogues/illuminatedmanuscripts/ILLUMINBig. ASP? size $=$ big\&IllID $=43455$.

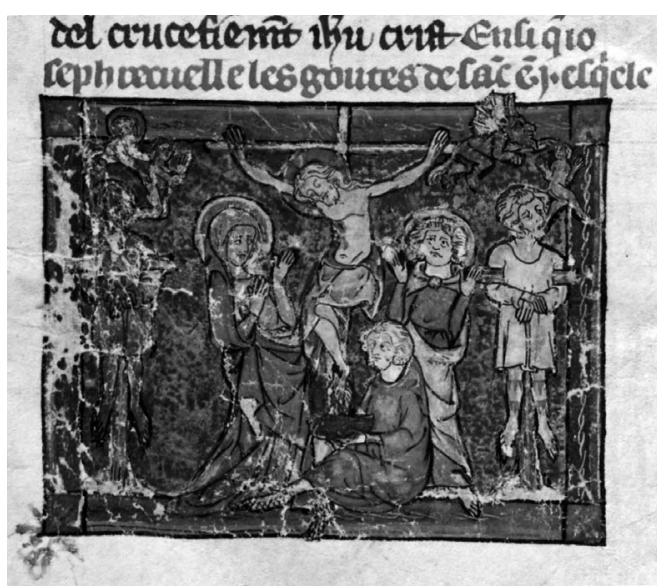

Slika 3: Križanje; pribl. 1315-1325, British Library, Additional 10292, f. 3v. Vir: http://www.bl.uk/manuscripts/FullDisplay.aspx?ref=Add_MS_10292.

Skupni motivi na vseh treh upodobitvah Križanja so križani Kristus, Marija in apostol Janez na straneh pod križem ter moški, ki sedi neposredno pod križem in $\mathrm{v}$ skledo zbira kri, ki teče iz Kristusovih ran. Samo v A je na vrhu razpela tabla z napisom $\mathrm{INRI}^{6}$ in samo tu je nad Marijo upodobljeno sonce, nad Janezom pa luna. Ne napisa ne sonca in lune ni v obeh londonskih rokopisih, sta pa upodobljena razbojnika, ki sta bila križana hkrati s Kristusom in ki ju ni v rkp. A. Način njune smrti je prikazan kot drugačen od načina smrti Božjega sina: njune roke niso razpete, temveč ovite okrog prečnega dela križa in nato povezane na trebuhu, na njunih nogah pa so nad in pod

6 Besedilo Estoire ga ne omenja, poročajo pa o njem vsi štirje evangelisti. 
koleni sledovi krvi, ki se navezujejo na evangeljski podatek, da so jima polomili noge. ${ }^{7}$ Razlika med obema upodobitvama je v tem, da sta v C nad razbojnikoma upodobljena še angel in hudič, ki odnašata njuni duši, izhajajoči iz njunih ust: duša desnega razbojnika je v položaju molitve, kleči in ima sklenjene roke, duša pogubljenega levega razbojnika pa se sicer ozira nazaj h križu, a razkoračeno stoji in tudi roke razprostira v obupu. V B dušici, angel in hudič niso upodobljeni, drži pa apostol Janez v svoji levici knjigo. ${ }^{8}$ Vsi omenjeni motivi, razen moškega, sedečega pod križem, imajo torej svetopisemski izvor.

Bistveni elementi na sliki za razbiranje pomena podobe so tisti, ki so skupni vsem trem rokopisom: Križani, Marija in Janez ter mož pod križem, Jožef iz Arimateje. Preden pa si njihove mogoče pomene podrobneje ogledamo, je vendarle treba premisliti, kakšen je »raison d’être« preostalih, »dodatnih« elementov. Pri tem za pričujočo raziskavo ni pomembno, ali je izhodiščni rokopis, na podlagi katerega so vsi trije obravnavani (posredno ali neposredno) nastali, vseboval samo »nujne« ali tudi »dodatne ( (razbojnika, njuni duši z angelom oz. hudičem, Sonce in Luno, napis INRI) elemente, saj to ne vpliva na presojo, ali navzočnost »dodatnih« elementov bistveno prispeva k pomenu slike (podobi) ali ga le dopolnjuje, poudarja, podpira ali pa niti to ne in bi jih bilo zato treba razlagati kot posledico slogovne odločitve.

Pomembno spoznanje je, da ne »nujnih « ne »dodatnih « elementov ne moremo utemeljiti glede na to, ali so omenjeni v besedilu rokopisov ali ne, da torej slika ni "gola« ilustracija besedila. Celo več: križanje kot dogodek, kot prizor v Estoire sploh ni opisano, tako da bi bilo prej mogoče reči, da slika ni ilustracija besedila, ki ji sledi; drugače rečeno: besedilo slike neposredno ne pojasnjuje, kar pomeni, da je bralec samo z branjem, brez miselne interpretativne dejavnosti ni mogel opomeniti. To ne pomeni, da številnih elementov, ki so na sliki prisotni, v besedilu ne bi bilo, marveč da v njem niso neposredno pripeti na konkretni zgodovinski dogodek križanja. Devica Marija tako npr. ni omenjena kot stoječa pod križem, temveč kot ena od redkih, ki so v času njegove smrti verjeli v Kri-

7 Ta podatek je samo v Janezovem evangeliju, kar se lepo sklada $\mathrm{z}$ navzočnostjo apostola Janeza na miniaturah. Gl. Jn 19, 31-37: »Ker je bil dan pripravljanja in zato, da telesa čez soboto ne bi ostala na križu (kajti tisto soboto je bil velik praznik), so Judje prosili Pilata, naj bi jim strli noge in jih sneli. Prišli so torej vojaki in strli noge prvemu in drugemu, ki sta bila križana z Jezusom. Ko so prišli do Jezusa in videli, da je že mrtev, mu niso strli nog, ampak mu je eden izmed vojakov s sulico prebodel stran in takoj sta pritekli kri in voda. Tisti, ki je videl, je pričeval in njegovo pričevanje je resnično. On ve, da govori resnico, da bi tudi vi verovali. To se je namreč zgodilo, da se je izpolnilo Pismo: Nobena izmed njegovih kosti se ne bo zlomila. In spet drugo Pismo pravi: Gledali bodo vanj, ki so ga prebodli.«

8 To pomeni, da je rkp. B najbliže vsebini Janezovega evangelija: v njem sta namreč razbojnika in njun konec omenjena, ni pa povedana zgodba o spreobrnjenju desnega in zakrknjenosti levega (o tem govori le evangelist Luka, gl. Lk 23, 39-43). V Janezovem evangeliju sta pod križ postavljena tudi Marija in Janez, učenec, ki ga je Jezus ljubil (Jn 19, 25-27), in v njem je Janez (avtor evangelija) označen kot očividec in pričevalec za resnico povedanega (gl. op. 7). Samo v Janezovem evangeliju Jezus nagovori mater in Janeza. Cf. tudi Schiller, 1968, Bd. 2, 99. 
stusa kot odrešenika; enako so opredeljeni apostoli, ne da bi bil kateri imenovan. Motiv rešenega desnega razbojnika je prikazan s perspektive umirajočega Kristusa, ki je na meji obupa, ker je do tega trenutka njegovo trpljenje rešilo le tega edinega grešnika, motiv smrti zaradi polomljenih nog pa je tudi omenjen kot mimogrede: Jožef iz Arimateje vidi, da je Jezus mrtev, hkrati pa to vidijo vojaki in mu zato ne polomijo nog, kot so storili z drugima križanima. ${ }^{9}$ Med motivoma rešenega desnega razbojnika in smrti zaradi polomljenih nog je daljša predstavitev Jožefa iz Arimateje, v kateri je opisana tudi njegova pridobitev sklede, iz katere je Jezus pri zadnji večerji jedel; ko to izvrši, se vrne na Kalvarijo in vidi, da je Kristus mrtev. Na kratko: neposredna povezava s križanjem kot dogodkom je le pri motivih razbojnikov (rešitvi desnega, polomljenih nogah obeh), ostali elementi (Marija, Jožef iz Arimateje, skleda zadnje večerje - sveti gral) pa v besedilu niso neposredno vezani na dogajanje pod križem; apostol Janez ni niti imenovan. Tolikšne razlike so dovoljšen razlog, da se vprašamo, ali so bili besedilni podatki zadostni za bralčevo opomenjenje slike oz. ali so bili edino, kar je usmerjalo njegovo razumevanje podobe.

Ker gre za zelo razširjen in zato dobro znan motiv, smemo domnevati, da ga je bralec prepoznal nemudoma, ne šele po branju besedila. Za identifikacijo večine elementov (razbojnika, Marija in Janez) je bilo »dovolj« poznavanje evangelijev; ${ }^{10}$ da je bilo to včasih celo nujno, potrjuje primerjava razlik med besedili in upodobitvami motiva rešenega desnega razbojnika ter motiva smrti razbojnikov zaradi polomljenih nog $\mathrm{v}$ obravnavanih kodeksih. Oba $\mathrm{z}$ razbojnikoma povezana motiva sta omenjena le $\mathrm{v}$ dveh od treh obravnavanih kodeksov: $\mathrm{v} \mathrm{B}^{11}$ in $\mathrm{A},{ }^{12} \mathrm{C}$ pa omenja le rešitev desnega razbojnika (f. $3 \mathrm{v}$ ), zato je še toliko bolj presenetljivo, da sta oba elementa upodobljena le v njem. ${ }^{13}$ To pomeni, da si motiva polomljenih nog na podlagi spremljajočega besedila ni bilo mogoče razložiti in ga je bralec lahko prepoznal le, če je poznal ustrezni evangeljski odlomek. Drugače pa je z motivom Jožefa iz Arimateje pod križem, ki ga evangeliji ne omenjajo, besedilo Estoire pa v taki postavitvi tudi ne: dejanje zbiranja krvi v sveti gral opiše povsem drugače. Zbiranje se dogodi v grobnici, kamor Jožef Jezusa položi, potem ko ga sname s križa; skledo, ki jo je Jezus uporabljal pri zadnji večerji, zdaj napolni z njegovo krvjo, jo nato odnese domov, se vrne v grobnico in Kristusovo telo spoštljivo pripravi za pokop. Bralec je osebo pod križem zato kot Jožefa iz Arimateje lahko

9 Ustrezni mesti navajam iz kritične izdaje Estoire del saint Graal Jean-Paula Ponceauja. Rešitev desnega razbojnika: »il veoit ke sa mours n'avait encore nului rachaté, ne il ne voit nului qui il eüst conquis par sa mort ke seulement le larron qui li cria le merchi en la crois«(Ponceau, 1997, 22, § 31). Način smrti razbojnikov: »Et quant il seut ke li Sauveres du monde estoit mors et ke chil l'avoient trové mort qui il voloient briser les cuisses autresi com as autres larrons« (Ponceau, 1997, 24, § 34).

10 Gl. op. 7 in 8. Evangeljski element, ki je navzoč na upodobitvah v vseh treh rokopisih, besedilo Estoire pa ga ne omenja, je apostol Janez.

11 Rešitev desnega razbojnika - f. 6v, način smrti razbojnikov - f. 7r.

12 Rešitev na f. 6r, smrt na f. 6v.

$13 \mathrm{~V}$ B »manjka« rešitev desnega razbojnika, v amsterdamskem rkp. pa oba motiva. 
identificiral le na podlagi rubrike nad miniaturo. V A je rubrika Chi est ensi que Joseph rechut le sanc Nostre Seignour qui puis fu apeleis Graalz, v B Ensi que Josephs recoilli le degout du sanc qui issoit des plaiies Nostre Seigneur qui puis fu apeles li saint Graalz, $\mathrm{v}$ C pa Ensi que Joseph recuelle les goutes de sanc en i esquiele (Meuwese, 1999, 199). Vse rubrike torej napovedujejo, da bo bralcu v nadaljevanju pojasnjeno, kako je iz posode, iz katere je Jezus obedoval pri zadnji večerji, nastal sveti gral. Besedilo, ki opisuje, kako je Jožef prišel do posode, je v B in A neposredno nad rubriko in miniaturo, del o napolnitvi posode s krvjo pa neposredno pod njima; v C je nekoliko bolj oddaljeno, a se vendarle začne na istem foliju, na katerem je tudi upodobitev. Pojasnilo, ki ga ponuja slika, in besedilno pojasnilo sta tako postavljeni dovolj blizu, da med njima zaradi različnosti nastaja pomenska napetost. Zato se moramo vprašati, ali je pomen slike $\mathrm{v}$ resnici dovolj pojasnjen, če se zadovoljimo samo z identifikacijo posameznih motivov, posameznih elementov slikovnega »teksta«, ali pa je treba za pravo razumevanje podobe, ki jo slikovni »tekst« sugerira, upoštevati še kaj drugega. S tem smo se vrnili k vprašanju o »nujnih « in »dodatnih « elementih, pri čemer se zdaj ne sprašujemo več, ali je njihova navzočnost na sliki utemeljena in upravičena, ne sprašujemo se torej o njihovem (besedilnem) viru, temveč nas zanima, kaj njihova navzočnost pomeni $\mathrm{v}$ okviru motiva Križanja kot celote. Da bi prišli do odgovora na to vprašanje, moramo najprej upoštevati splošni ikonografski pomen tega motiva, torej tistega, ki mu je bil kot celoti ali njegovim posameznim gradnikom pripisan $\mathrm{v}$ zgodovinskem razvoju do časa nastanka obravnavanih rokopisov, predvsem pa v njihovi »ožji« sočasnosti, tj. v 12. in 13. stoletju. Zastaviti si moramo torej vprašanja, kot so: Kaj pomenita Marija in Janez pod križem? Kaj pomeni oseba, postavljena pod križ, ki v posodo zbira Kristusovo kri? Je upodobitev razbojnikov le ilustracija svetopisemskega podatka ali ima še kak drug pomen? Pomene, do katerih se bomo dokopali z odgovori na ta vprašanja, je nato treba preveriti v kontekstu besedila in drugih miniatur v obravnavanih kodeksih: če pri tem obvisijo v zraku, jih v interpretaciji podobe ne moremo upoštevati; če gre za pomene, ki jih besedilo in nadaljnje miniature razvijajo, pa jih lahko sprejmemo kot mogoče.

\section{Analiza pomenov}

$\mathrm{V}$ vseh treh rokopisih je Kristus upodobljen enako: to je mrtvi Kristus, o čemer pričajo zaprte oči in prebodena stran, trpeči Kristus, ki ni prikazan kot zmagovalec nad smrtjo, temveč ponižani in zasmehovani, ki so mu odvzeti vsi atributi zmagoslavja nad smrtjo. Teološki pomen te podobe je, da je krščanski Bog tudi žrtveni dar. ${ }^{14}$

14 Cf. Wirth, 2010, zlasti 234-235, 240. Gertrud Schiller že ob analizi (pozno)karolinških upodobitev Križanja ugotavlja, da je treba vedno, kadar je poudarjena kri, ki teče iz ran Križanega, podobo razumeti kot upodobitev Kristusove smrti in njegovega odrešenjskega dejanja, ne glede na to, ali gre za tip zmagovitega ali trpečega Križanega (cf. Schiller, 1968, Bd. 2, 129). 
Marija in Janez pod križem sta v tem času predvsem žalujoči figuri, ki podpirata osnovni namen motiva trpečega Kristusa: upodobljena krutost trpljenja naj gane vernega gledalca. ${ }^{15}$ Žalujoča, sočutna Marija in Janez sta povabilo gledalcu $\mathrm{k}$ podobnemu čustvovanju (Wirth, 2010, 240). Na obravnavanih miniaturah lahko na tovrstna čustva sklepamo tudi iz Marijinih in Janezovih gest.

V rkp. A Marija na prsih svojo levico drži z desnico, kar izraža nezmožnost poseči v dogajanje oz. spremeniti njegov tek. Gesta označuje človeka, ki se je po zakonih nujnosti znašel v neobhodnem, nespremenljivem, dramatičnem položaju, v primeru amsterdamske Marije je mogoče reči celo natančneje: kar jo žalosti, jo neposredno zadeva, čeprav je neodvisno od njene volje, vloga, v katero je postavljena, je posledica sil, ki jih ne nadzira. ${ }^{16}$ Zagonetnejša je drža Janezovih rok; njihova spuščenost navzdol bi lahko pomenila nemoč (Garnier, 1995, 214) ob dogajanju, ki mu je priča, a med njegovo in Marijino gesto je opazna razlika: medtem ko Marija levico drži z desnico, so Janezovi prsti obeh rok prepleteni. ${ }^{17}$ Marija in Janez obračata pogled stran od križa, kar lahko interpretiramo kot sklanjanje glave v bolečini (Garnier, 1995, 141). Nekoliko drugačna je gestikulacija v B. Drža Marijinih rok je podobna, le bolj dinamična, Janez pa v levici drži knjigo, desnico pa odpira proti Križanemu ali proti Mariji. Ne gre za gesto kazanja, temveč za gesto sprejemanja (Garnier, 1995, 174), pogled pa usmerja horizontalno, ne navzgor, torej bolj proti Mariji kot proti Kristusu. Knjiga je sicer značilni atribut apostola Janeza (Lechner, 1974, 112), a njegovo upodobitev v B je vredno primerjati z upodobitvijo Marije ob Oznanjenju v zakramentarju iz 13. stoletja, ki jo kot primer navaja Garnier ${ }^{18}$ - Marija prav tako v levici drži knjigo, desnica pa je v enakem gibu sprejemanja odločitve drugega, ubogljivosti ukazu. Zaradi te identičnosti in zaradi Janezovega pogleda, (domnevno) usmerjenega na Marijo, bi lahko podobo interpretirali kot Janezovo sprejemanje edinega »ukaza «, ki ga je dobil pod križem, namreč da Marijo sprejme za svojo mater. Križanje v C je, kar se gest Marije in Janeza tiče, enostavnejše, saj oba razpirata dlani pred prsmi v znak sprejemanja Božje volje.

15 Wirth pravi, da je bil ta namen glavni povzročitelj razvoja motiva križanja s tremi žeblji, ki vodi do uresničitve, kakršna je tudi v vseh treh tu obravnavanih rokopisih: Kristusove noge nimajo več opore v suppedaneumu, ki je bil hkrati neke vrste piedestal in s tem znamenje oblasti, zato vsa teža telesa obvisi na rokah, ki so tako stegnjene, napete, telo pa oblikuje cikcakasto linijo, saj se dvakrat ukrivi, $\mathrm{v}$ kolenih in bokih. Cf. Wirth, 2010, 234-240. O vživljanju v bolečino oseb pod križem (zlasti Marijino) govori tudi Schiller, 1968, Bd. 2, 21.

16 Gesto natančno analizira Garnier, 1995, 198, povzemam od tod. Cf. tudi Garnier, 2003, 103.

17 Zaenkrat te podrobnosti ne znam pojasniti.

18 Cf. 1995, 174-177; ilustracija H na str. 177. 
V zvezi z Marijo in Janezom pod križem moramo premisliti še simboliko, ki izhaja iz njune postavitve na mesti pod križem, kjer sta svoj čas stali Eklezija in Sinagoga. Wirth ugotavlja, da se je križanje v 12. in 13. stoletju razvijalo v smeri poenostavitve: pod križem sta ostala le Marija in Janez, ${ }^{19}$ katerih namen je bil, kot rečeno, vzbujati sočutje do Kristusovega trpljenja, dogmatični pomen pa je začel izginjati (njegovi nosilni elementi so bili predvsem Longin, ki prebada Kristusovo stran, Eklezija in Sinagoga), kar je bila posledica tudi tega, da so te umetnine nastajale za laike izpod rok laikov (Wirth, 2010, 238-240). Drugače je menil Émile Mâle: po njegovem so se pomeni, ki sta jih prej samostojno nosili upodobitvi Eklezije in Sinagoge, zdaj zlili s figurama Marije in Janeza (Mâle, 2000, 188-192). Za nobeno od obravnavanih treh upodobitev ne moremo zatrditi, da sta bodisi Marija bodisi Janez bodisi oba nosilca pomenov Eklezije in Sinagoge, hkrati pa te možnosti ne moremo enoznačno odpraviti. Na miniaturi v rkp. A bi lahko npr. Janezove spuščene roke, sklonjeno glavo in odvračanje od križa povezali z značilnimi upodobitvami Sinagoge, ${ }^{20}$ a takšna interpretacija ne zdrži, ker se podobno odvrača tudi Marija ${ }^{21}$ - njuni postavitvi tako lahko razumemo le kot žalost. V rkp. C bi lahko edino razliko med Marijo in Janezom izpeljali iz strani križa, na katero sta postavljena, saj sicer, kot rečeno, gestikulirata enako - Janez je na levi strani; in ker gre za rokopis, v katerem sta križana razbojnika najnazorneje upodobljena, to pomeni, da je nad Janezom upodobljen hudič, ki v pekel odnaša dušo zakrknjenega levega razbojnika, nad Marijo pa angel, ki v nebesa odnaša dušo spreobrnjenega. Vendar pa bi bilo skleniti, da se negativna oz. pozitivna konotacija prenaša tudi na figuri pod križem, preveč domišljijsko, predvsem pa povsem arbitrarno, ne da bi se lahko sklicevali na kak resen dokaz. Nam pa upodobitev preklete dušice omogoča premislek, ali gesti Marije in Janeza (razprte dlani pred prsmi) res pomenita sprejemanje Božje volje, torej pomen, ki ga za to gesto ugotavlja Garnier prekleta duša zakrknjenega razbojnika namreč roke drži enako kot onadva, pri čemer se zdi verjetneje, da je to izraz duše, ki je »žalostna do smrti«, izraz groze. Da Marija in Janez izražata takšno čustvo, je tudi bolj skladno z Wirthovo tezo, da je njuna funkcija na upodobitvah Križanja tega časa vzbujanje sočutja pri bralcu/gledalcu, hkrati pa je tak pomen blizu tistemu, ki ga imata v rkp. A. Skratka: ne za rkp. A ne za rkp. C ni mogoče utemeljeno domnevati, da bi figuri Marije in Janeza sugerirali tudi pomena Eklezije in Sinagoge, zato smemo reči, da ti upodobitvi ne sodita med tiste »nekatere primere, v katerih Devica simbolizira Cerkev« (Mâle, 2000, 190), apostol Janez pa

19 Karolinško Križanje z več osebami (Marijo in Janezom na robovih, Eklezijo, Sinagogo ter vojakoma, od katerih eden prebada Kristusovo stran, drugi pa mu ponuja z žolčem napojeno gobo, pod križem) se je že v zgodnji romaniki razvilo tudi do "preprostega " Križanja le s tremi osebami, tj. Kristusom, Marijo in Janezom, do tipa, ki je v gotiki prevladal. Cf. Jászai, 1970, 620-627.

Cf. npr. Schiller, 1976, Bd. 4, 46-47. 
Sinagogo. Morda pa smemo biti nekoliko drznejši pri interpretaciji slike v rkp. B, kjer Janezove geste, kot rečeno, nakazujejo njegovo sprejemanje Kristusovih besed o Mariji kot svoji materi in sebi kot njenem sinu. Gre torej za osnovanje občestva, s tem pa za zametek Cerkve. Tudi tu torej ne moremo ugotoviti, da bi figuri Marije in Janeza prevzeli pomene, ki sta jih v starejši umetnosti imeli na »njunih « mestih stoječi Eklezija in Sinagoga, vendar pa je mogoče zaslutiti ekleziološki pomenski odtenek, ki izhaja iz svetopisemskega odlomka v Janezovem evangeliju (in ne pozabimo: edino na upodobitvi rkp. B Janez v roki drži knjigo), potrjuje pa ga tudi stavek v besedilu Estoire, ki sploh edini omenja Marijo in apostole v zvezi z dogodkom križanja: označi jih kot redke, ki so v trenutku Jezusove smrti že verjeli vanj kot Kristusa, Božjega sina, torej: kot zgodnjo, prvo Cerkev. ${ }^{22}$

Od elementov, ki smo jih imenovali »bistveni« ali »nujni«, nam je ostal še pod križem sedeči Jožef iz Arimateje, ki v skledo zbira kri, tekočo iz Kristusovih ran. Povedali smo, da upodobitev tu ni ilustracija besedila, saj je tam dejanje opisano povsem drugače, zato se moramo vprašati, kakšen pomen je bralec/gledalec pripisoval takšni očitni razliki, kar pomeni tudi, da je na mestu vprašanje, ali je bila figura pod križem, ki v posodo zbira Kristusovo kri, znan motiv. Odgovor je: da, čeprav ta oseba ni sedela pod križem, ampak je stala na Kristusovi desnici, in tudi ni bila moški, temveč ženska. ${ }^{23}$ Figura, ki je v posodo, točneje, v kelih pod križem zbirala Kristusovo kri, je bila od karolinškega obdobja naprej personifikacija Eklezije (Schiller, Bd. 2, 1968, 117-118). Cerkev se je namreč po interpretaciji cerkvenih očetov rodila iz prebodene Kristusove strani, od koder sta pritekli kri in voda; prebodena stran je tako simbol dveh glavnih zakramentov: krsta in evharistije (maše) (Mâle, 2000, 187). Motiv Križanja, kjer sta nad zgodovinskostjo na ta način, s poudarjeno pozornostjo do prebodene Kristusove strani, prevladali simboličnost in evharističnost, je značilen že za karolinško umetnost (Wirth, 2008, 97), od sredine 11. stoletja pa je bil vse bolj poudarjen darovanjski vidik: za kruh in vino so v času Otoncev začeli uporabljati izraz hostia, tj. darovanjska žrtev, zlasti od sredine 11. stoletja pa evharistična daritev velja za ponavljajoče se žrtvovanje Boga, čigar telo in kri verniki uživajo. Vse bolj je poudarjena vloga duhovnika, ki »ustvari«, »naredi« Kristusovo telo, ki omogoči »inkorporacijo« vernikov v Kristusa, tj. nastanek mističnega telesa - Cerkve. ${ }^{24} \mathrm{~V}$ ikonografski tradiciji je bila torej oseba pod križem, ki

22 V kritični izdaji se ta stavek glasi: "a chel jour estoit encore mout peu de gent qui creïssent en lui, en mais ke la glorieuse Virge Puchiele, sa douche mere, et ses desciples, qui a chel jour estoient apielé si 'frere’. Et s'il en i avoit des autres qui creïssent, mout en i avoit cler « (Ponceau, 1997, 22, § 31). V bolj ali manj takšni obliki je zapisan v rkp. A in B, v rkp. C pa Devica Marija ni posebej imenovana, stavek se glasi: »A i cel ior estoient moult poi de gent qui en lui creoient fors si desciple.«

23 To velja za zahodno umetnost, v srednjebizantinski umetnosti pa je obstajal motiv žene, klečeče ob vznožju križa s kelihom; na Zahodu se ni razširil, kar pa ne pomeni, da zanj niso vedeli - in sicer že v 10. stoletju; cf. Schiller, 1976, Bd. 4, 48. 
je v posodo (kelih) lovila Kristusovo kri, enoznačno povezana s temi poudarki, zato smemo domnevati, da je tudi Jožef iz Arimateje, ki glede na besedilo pod križem v tej obliki nima česa iskati, na obravnavanih miniaturah postal nosilec teh pomenov. Takšen pomen je skladen tudi z nadaljevanjem besedila Estoire: Jožef je prvi varuh grala, torej prvi varuh evharistične »skrivnosti«, hkrati pa prvi voditelj Cerkve, ki nastane še v Judeji, prvi, ki razloži pomen krsta, in prvi misijonarski oznanjevalec. ${ }^{25}$ Obenem je figura, ki sugerira evharistijo, kot jo je razlagala Cerkev, v sozvočju z upodobljenim tipom trpečega Kristusa, ki poudarja žrtveni vidik Božjega darovanja in odrešenja, ki je zgoščeno izražen tudi v prvem stavku »poglavja «. ${ }^{26}$

Analizo pomenov lahko torej sklenemo z domnevo, da je podoba, ki jo bralec/ gledalec oblikuje na podlagi slike Križanja v treh obravnavanih rokopisih, podoba Božjega odrešenjskega dejanja, tj. Kristusovega trpljenja in krute smrti na križu, ki se nadaljuje v evharistični daritvi, kot jo predpisuje in uresničuje Cerkev. Ta iz tega odrešenjskega dejanja na eni strani izvira, na drugi pa je njegov varuh (skrbnik skrivnosti) v času, ki sledi. Gre torej za ekleziološko-evharistično podobo. Ali je res tako, je treba preveriti še z zadnjim prej postavljenim kriterijem, tj. s preverjanjem, ali takšen pomen potrjuje tudi nadaljevanje slikovne naracije v posameznem kodeksu, ali je ekleziološko-evharistični pomen ena od razvijanih tem pripovedi, ena od njenih rdečih niti. Za analizo vseh slik, ki jih je na pomenski ravni mogoče povezati s to temo, $\mathrm{v}$ tem članku ni prostora, zato se omejujem le na naštetje in minimalno identifikacijo miniatur, ki podpirajo tu predlagano interpretacijo Križanja, torej miniatur $\mathrm{z}$ ekleziološko-evharistično temo. Na nekaterih slikah lahko v ospredje pride ena od obeh tem, na večini pa sta združeni. ${ }^{27}$

Rokopis A: 1r (pripovedovalec - puščavnik časti križ, ${ }^{28}$ postavljen na oltar), 1v (samo ekleziološka tema: Kristus se puščavniku - pripovedovalcu prikaže v oblaku, iz katerega na Zemljo padajo plameni), ${ }^{29} 18$ r (Josephé ${ }^{30}$ kot prvi škof v liturgični opravi, na oltarju s prtičem pokrit kelih, skleda in okrvavljeni žeblji ter vrh sulice, s katero je

25 Ponceau, 1997, 37-38, \$\$ 55-56, in 39, \$ 58 ss.

26 »Au jour ke li Sauveres du monde souffri mort, par la qui mort nostre mors fu destruite et confundue et nostre vie restoree pardurablement ...« (Ponceau, 1997, 22, \$31).

27 Tokrat ne naštevam miniatur $\mathrm{z}$ upodobitvami razprave med kristjani in pogani, čeprav imajo seveda tudi te ekleziološki pečat; omejujem se na tiste, kjer je izrazit evharistični ali zakramentalni pomen.

28 V velikonočni liturgiji je v nekaterih primerih križ že v karolinškem času pomenil Kristusovo telo in je bil zamenljiv s hostijo; cf. Wirth, 2008, 51.

29 Upodobitev plamenov, ki padajo z nebes na Zemljo, je tipičen element na upodobitvah binkošti (cf. npr. Seeliger, 1971, zlasti 417), ki veljajo za ustanovitev Cerkve. Pripovedovalec po tem srečanju občuti, da more govoriti v številnih jezikih, kar je eden od binkoštnih darov sv. Duha apostolom (cf. Ponceau, 1997, 3, \$5).

30 Josephé je sin Jožefa iz Arimateje, ki ga Kristus sam posveti v škofa in na katerega se prenese vodstvena funkcija med kristjani, ki jih je dotlej vodil njegov oče. 
bila prebodena Kristusova stran), 21r (Kristus in Josephé obhajata klečeče vernike), 88v (evharistični čudež - skleda s Kristusovo krvjo, sveti gral, omogoči hojo prek morja; ker je Josephé v škofovskem ornatu, je ekleziološki pomen pridružen), 100v (pokop mučencev - zakramentalno dejanje), 101v (gralova miza - vizualna aluzija na zadnjo večerjo), 113r (škof Josephé mazili kralja - zakrament, privilegij Cerkve), 114v (Josephé preda gral Alainu - neke vrste apostolsko nasledstvo).

Rokopis B: 3r (puščavnik - pripovedovalec časti kelih, pokrit s prtičem, postavljen na oltar), $14 \mathrm{v}$ (kristjani molijo pred oltarjem, na katerem je s prtičem pokrit kelih, z neba se prikaže Bog in iz njegovih ust se na vsakega molivca izlije žarek - »binkošti«), $17 \mathrm{v}$ (Kristus in Josephé obhajata kristjane), 66v (škof Josephé s spremstvom hodi po morju), ${ }^{31} 76 \mathrm{r}$ (Josephé ukaže pokopati mučence - zakrament), 76v in 77v (gralova miza - vizualna aluzija na zadnjo večerjo), 81v (Josephé tolaži ranjenega Pierrona aluzija na zakrament bolniškega maziljenja oz. sv. popotnice), $84 \mathrm{v}$ (Josephé mazili kralja), 86r (Josephé preda gral Alainu - »apostolsko« nasledstvo).

Rokopis C: 1r (puščavnik - pripovedovalec časti kelih, pokrit s prtičem, postavljen na oltar), 8r (kristjani molijo pred oltarjem, na katerem je s prtičem pokrit kelih, z neba se prikaže Božje obličje, iz njegovih ust poleti golob sv. Duha, iz njegovega kljuna pa se na vsakega molivca izlije žarek - »binkošti«), 9v (Kristus umesti škofa Josephéja, na oltarju je vidna hostija), 33r (Kajn ubije Abela - predpodoba Kristusove smrti), 55v (škof Josephé s spremstvom hodi po morju), 63r (škof Josephé daruje mašo), 64v in 65r (gralova miza - vizualna aluzija na zadnjo večerjo), 73r (Josephé preda gral Alainu - »apostolsko« nasledstvo).

Za konec moramo oceniti, kakšen je pomen navzočnosti elementov, ki smo jih imenovali »nenujne«. Če sledimo Émilu Mâlu, bi spet lahko rekli, da zadoščata njuni postavitvi na Kristusovo desnico oz. levico (Mâle, 2000, 192): rešeni razbojnik je tako podoba Cerkve, pogubljeni pa Sinagoge, a takšna interpretacija je celo za miniaturo v rkp. C, ki je edina od obravnavanih treh, na kateri sta jasno nakazana pogubitev in odrešenje razbojnikov, pretirana; postavljenost na levo oz. desno tako kot v primeru Janeza in Marije pač ni zadosten dokaz za takšno razlago. Tudi upodobitev sonca in lune na miniaturi rkp. A ni mogoče dopolnjujoče vključiti v pomen podobe Križanja v tem kodeksu. Tako kot »nujni« elementi preostanejo res tisti, ki so - z izjemo planetov - upodobljeni na amsterdamski miniaturi: Križani kot mrtvi Bog, kot žrtev darovanja, iz katerega je nastala Cerkev; Jožef iz Arimateje kot nosilni element te prvotne Cerkve; ter Marija in Janez kot žalujoči osebi pod križem, katerih funkcija na sliki je, da dogodek na Kalvariji posedanjita za bralca, ki se z njuno žalostjo zaradi Kristusove smrti lahko poistoveti.

31 Na tej miniaturi za razliko od tiste na f. 88v rkp. A sveti gral ni upodobljen, zato samo na podlagi slikovnih elementov ni mogoče govoriti o evharističnem čudežu. 


\section{Bibliografija}

Bal, M., Narratology. Introduction to the Theory of Narrative. Toronto, Buffalo, London 1997.

Carruthers, M., The Craft of Thought. Meditation, rhetoric, and the making of images, 400-1200, Cambridge 1998.

Garnier, F., La langage de l'image au Moyen-Âge I - Signification et symbolique, Pariz 1982.

Garnier, F., La langage de l'image au Moyen-Âge I - La grammaire des gestes, Pariz 2003.

Greisenegger, W., Ecclesia und Synagoge, Lexikon der christlichen Ikonographie 1, Freiburg im Breisgau 1968, str. 569-578.

Jászai, G., Kreuzigung Christi, Lexikon der christlichen Ikonographie 2, Freiburg im Breisgau 1970, str. 606-642.

Lechner, M., Johannes der Evangelist (der Theologe), Lexikon der christlichen Ikonographie 7, Freiburg im Breisgau 1974, str. 108-130.

Loomis, R. S., Loomis, L. H., Arthurian Legends in Medieval Art, London 1938.

Mâle, E., Religious Art in France of the Thirteenth Century, Mineola 2000.

Meuwese, M., Three Illustrated Prose Lancelots from the same Atelier, Text and Image. Studies in the French Illustrated Book from the Middle Ages to the Present Day, Manchester 1999.

Ponceau, J. P. (ur.), L'Estoire del saint Graal, Pariz 1997.

Schiller, G., Ikonographie der christlichen Kunst, Band 2: Die Passion Jesu Christi, Gütersloh 1968.

Schiller, G., Ikonographie der christlichen Kunst, Band 4, 1: Die Kirche, Gütersloh 1976.

Seeliger, S., Pfingsten, Lexikon der christlichen Ikonographie 3, Freiburg im Breisgau 1971, str. 415-423.

Stones, A., Gothic Manuscripts: c. 1260-1320. Part 1. A Survey of Manuscripts Illuminated in France, zv. 1, Turnhout 2013a.

Stones, A., Gothic Manuscripts: c. 1260-1320. Part 1. A Survey of Manuscripts Illuminated in France, zv. 2, Turnhout 2013b.

Wirth, J. L’image à l’époque gothique (1140-1280), Pariz 2010. 


\section{Miha Zor}

\section{Križanje, Cerkev in evharistija $v$ treh arturjanskih rokopisih}

Ključne besede: Križanja, Cerkev, evharistija, ikonografija, knjižno slikarstvo, Estoire del saint Graal

Članek obravnava tri miniature z upodobitvijo Križanja iz treh rokopisov romance Estoire del saint Graal. Obravnavani rokopisi so: dva iz British Library (signaturi Royal 14.E.III in Additional 10292) ter eden, ki je danes v zasebni lasti, označuje pa ga nekdanja signatura Amsterdam BPH 1 (ex-Phillips 1045/7, 3630). Vsi trije so nastali na območju Saint-Omerja, Thérouanna, Tournaija in Ghenta med letoma 1315 in 1325. Razlike med tremi miniaturami so $\mathrm{v}$ podrobnostih in analiza se jih loteva $\mathrm{v}$ treh korakih. Najprej so določeni vsi mogoči pomeni posameznih motivov, nato se posvetimo vprašanju, kateri od teh pomenov so dejansko navzoči na obravnavanih miniaturah; zato so preučena razmerja med posameznimi motivi na sliki. Pomeni, pripisani posameznim motivom in sliki kot celoti, so nato preverjeni še z ozirom na ostale miniature v vsakem od rokopisov, da se razkrije, ali obstajajo tematske ali ideološke zveze in ali se razvija slikovna naracija, ki več posameznih miniatur povezuje v eno zgodbeno nit. Ti kriteriji so upoštevani, da bi lahko opisali pomen slike, tj. ekfrazo podobe, ki jo sugerira slikovni tekst. 
Miha Zor

\section{Crucifixion, the Church and the Eucharist in Three Arthurian Manuscripts}

Keywords: Crucifixion, Church, Eucharist, iconography, manuscript painting, Estoire del Saint Graal

This paper analyses three miniatures from manuscripts of the Estoire del Saint Graal, in which the Crucifixion is depicted. The three manuscripts considered are BL Royal 14.E.III, BL Add. 10292 and olim Amsterdam BPH 1 (ex-Phillips 1045/7, 3630), which were made in Saint-Omer, Thérouanne, Tournai and Ghent ca. 1315-1325. The differences between the miniatures concern details, and the analysis deals with these in three steps. Firstly, the possible meanings of each particular motif are searched for. Secondly, by establishing which meanings of these motifs are possible in the pictures in question, the relations between different motifs are taken into account. Thirdly, the meaning ascribed to particular motifs and to each picture as a whole is tested with regard to other miniatures in the manuscripts, in order to find out whether there is a thematic or ideological connection, and whether a pictorial narration is present that links several miniatures in one story line. These steps are followed with the aim of establishing a meaning of the pictures, i.e. the ekphrasis of the images, as suggested by the pictorial text. 